\title{
Tree-ring-based reconstruction of temperature variability (1445-2011) for the upper reaches of the Heihe River Basin, Northwest China
}

\author{
WANG Yamin ${ }^{1,2 *}$, FENG Qi ${ }^{1}$, KANG Xingcheng ${ }^{1}$ \\ ${ }^{1}$ Alxa Desert Eco-hydrology Experimental Research Station, Cold and Arid Regions Environmental and Engineering Research \\ Institute, Chinese Academy of Sciences, Lanzhou 730000, China; \\ ${ }^{2}$ University of Chinese Academy of Sciences, Beijing 100049, China
}

Abstract: Long-term temperature variability has significant effects on runoff into the upper reaches of inland rivers. This paper developed a tree-ring chronology of Qilian juniper (Sabina przewalskii Kom.) from the upper tree-line of the middle Qilian Mountains within the upper reaches of Heihe River Basin, Northwest China for a long-term reconstruction of temperature at the study site. In this paper, tree-ring chronology was used to examine climate-growth associations considering local climate data obtained from Qilian Meteorological Station. The results showed that temperatures correlated extremely well with standardized growth indices of trees $(r=0.564, P<0.001)$. Tree-ring chronology was highest correlated with annual mean temperature $(r=0.641, P<0.0001)$. Annual mean temperature which spans the period of 1445-2011 was reconstructed and explained $57.8 \%$ of the inter-annual to decadal temperature variance at the regional scale for the period 1961-2011. Spatial correlation patterns revealed that reconstructed temperature data and gridded temperature data had a significant correlation on a regional scale, indicating that the reconstruction represents climatic variations for an extended area surrounding the sampling sites. Analysis of the temperature reconstruction indicated that major cold periods occurred during the periods of $1450 \mathrm{~s}-1480 \mathrm{~s}$, 1590s-1770s, 1810s-1890s, 1920s-1940s, and 1960s-1970s. Warm intervals occurred during 1490s-1580s, 1780s-1800s, 1900s-1910s, 1950s, and 1980s to present. The coldest 100-year and decadal periods occurred from 1490s-1580s and 1780s-1800s, respectively, while the warmest 100 years within the studied time period was the $20^{\text {th }}$ century. Colder events and intervals coincided with wet or moist conditions in and near the study region. The reconstructed temperature agreed well with other temperature series reconstructed across the surrounding areas, demonstrating that this reconstructed temperature could be used to evaluate regional climate change. Compared to the tree-ring reconstructed temperature from nearby regions and records of glacier fluctuations from the surrounding high mountains, this reconstruction was reliable, and could aid in the evaluation of regional climate variability. Spectral analyses suggested that the reconstructed annual mean temperature variation may be related to large-scale atmospheric-oceanic variability such as the solar activity, Pacific Decadal Oscillation (PDO) and El Niño-Southern Oscillation (ENSO).

Keywords: tree-ring; climatic response; temperature reconstruction; upper reaches of Heihe River Basin

Citation: WANG Yamin, FENG Qi, KANG Xingcheng. 2016. Tree-ring-based reconstruction of temperature variability (1445-2011) for the upper reaches of the Heihe River Basin, Northwest China. Journal of Arid Land, 8(1): 60-76. doi: $10.1007 / \mathrm{s} 40333-015-0138-5$

\footnotetext{
*Corresponding author: Wang Yamin (E-mail: wangyamin@1zb.ac.cn)

Received 2014-09-24; revised 2015-03-01; accepted 2015-06-24

C Xinjiang Institute of Ecology and Geography, Chinese Academy of Sciences, Science Press and Springer-Verlag Berlin Heidelberg 2016
} 
Climate change has a significant impact on the processes of water resources and ecosystems in arid regions, especially in Northwest China (Stewart et al., 2004; Chen et al., 2010; Xu et al., 2011). Climate warming would speed global water cycle and strengthen rainfall and evaporation (Shi et al., 2002). The different warming conditions and the change of atmospheric oscillations will consequentially result in changes in the distribution of precipitation and runoff. The ascending of temperature in a mountainous area will accelerate snow melting, and therefore make surface flow and ground water increase (Li et al., 2006). Likewise, it will cause reduction of river flow by evaporation under the same precipitation condition in a plain area (Shi and Zhang, 1995; Gong and Wang, 2000). Therefore, temperature change has a significant effect on runoff in inland river areas, and it is also important for maintaining downstream ecosystems (Li et al., 2010; Zhou et al., 2010).

The Heihe River Basin is the second largest arid inland drainage basin in Northwest China. It is located in the transition zone between the monsoon and westerlies, and is important because of its ecological fragility and climatic sensitivity (Wang et al., 2003). The natural ecological environment in the Heihe River Basin has encountered serious degradation due to global climate change and human activities (Ma et al., 2005). Ecological environment in the upper reaches of a river is key to the protection of the whole watershed (Kundzewicz et al., 1997). There is a close relationship between the surface runoff and the air temperature in the upper reaches of Heihe River Basin, and the variation in air temperature will affect the socio-economic development and wildlife habitats in the Heihe River Basin to a certain extent (Kang et al., 1999). For this reason, researches on the variation characteristics and the trend of temperature has great significance to the future planning, utilization and management of water resources in the upper reaches of the Heihe River Basin.

However, most instrumental meteorological records in arid regions, especially in Northwest China, are less than 60 years, which is too short for investigating multi-decadal or longer-term climate variability (Yang et al., 2010). Hence, it is difficult to evaluate the characteristics of climate changes in the past. An enhanced understanding of past climatic variability in arid regions must rely on climatic proxies. Tree-ring is a valuable tool for the study of climate variability beyond the short period normally covered by instrument-recorded data, because of their easy availability, high resolution, and reliability (Fritts, 1976). So, time series of tree-ring growth measurements spanning several centuries serve as proxy records of past climatic conditions (Cook et al., 1999). The annual growth of a tree is the net result of many complex and interrelated biochemical processes. Trees interact directly with the microenvironment of their leaves and root surfaces. The fact that there exists a relationship between these extremely localized conditions and larger scale climatic parameters offers the potential for extracting some measures of the overall influence of climate on growth from year to year (Bradley, 1985). Growth of trees may be affected by many aspects of the microclimate, such as sunshine, precipitation, temperature, wind speed, and humidity (Fritts, 1976; Bradley, 1985). Long-term records produced by tree-ring studies have been used to extend these limited meteorological records, and can serve to evaluate the past frequency and severity of climatic anomalies (Pederson et al., 2001; D'Arrigo et al., 2003; Liu et al., 2009; Mann et al., 2009; Cook et al., 2010; Davi et al., 2010) and help anticipate the future probability of such events. Several tree-ring-based climate reconstructions have been developed in China (Zhang et al., 2003; Liu et al., 2004, 2006; Shao et al., 2005; Wang et al., 2005; Liang et al., 2006; Gou et al., 2007; Yuan et al., 2007; Cai et al., 2010; Li et al., 2012). The Qilian mountainous area, where patched forests of long-lived Qilian juniper (Sabina przewalskii Kom.) grow, has particularly been of recent interest for tree-ring studies in China (Kang et al., 1997, 2000; Shao and Fan, 1999, 2005; Zhang et al., 2003; Sheppard et al., 2004; Shao et al., 2005; Liu et al., 2005, 2006, 2009; Gou et al., 2008; Yang et al., 2010). As the upper reaches of Heihe River Basin, the middle Qilian Mountains had a multitude of tree-ring chronologies developed, which have revealed the variation of temperature, precipitation, drought, and runoff in the historic period (Kang et al., 2002, 2003; Gou et al., 2005; Liu et al., 2005, 2009; Tian et al., 2007; Liang et al., 2009; Chen et al., 2011; Qin et al., 2011; Yang et al., 2011; Zhang et al., 2011). However, most of the 
chronologies are used to reconstruct precipitation, runoff, and drought events. Long-term climate records for temperature variability still remain lacking in the upper reaches of Heihe River Basin.

In this study, a new temperature reconstruction, which derived from a new tree-ring-width chronology of Qilian juniper, was reported for the middle Qilian Mountains in the upper reaches of Heihe River Basin. Variations in terms of tree-ring width, geographical position, and characteristics and climate response patterns of the tree-ring were analyzed. The most responsible climate for tree radial growth was then identified and past climate changes were reconstructed using well calibrated and verified tree growth-climate relationships. The results were compared with previously developed temperature reconstructions from the surrounding regions. This reconstruction should improve our understanding of climate variability in this high and remote region.

\section{Study area and methods}

\subsection{Sampling site}

A tree-ring-width chronology was developed using increment cores extracted from Qilian juniper trees growing in the middle Qilian Mountains (Fig. 1). As the upper reaches of Heihe River Basin, the middle Qilian Mountains are sensitive to climate change (Wu and Shao, 1995). The tree growth is mainly limited by temperature at the upper tree-line and by precipitation at the lower tree-line (LaMarche, 1974; Fritts, 1976; Tessier et al., 1997). The tree-ring sampling site was located at the upper tree-line in the middle Qilian Mountains, which was higher in elevation and receives comparatively more precipitation than previous sampling sites. In alpine areas, temperatures are usually decreasing with increasing elevation, while precipitation usually increases (Glickman, 2000). Therefore, samples were collected from trees found growing in an alpine forest located between 3,246 and 3,484 $\mathrm{m}$ asl on southeast- and east-facing slopes adjacent to the Yuanbai valley of the middle Qilian Mountains $\left(38^{\circ} 01^{\prime} 08^{\prime \prime} \mathrm{N}, 100^{\circ} 04^{\prime} 03^{\prime \prime} \mathrm{E}\right.$; Fig. 1). The tree-ring cores were collected from the dominant Qilian juniper, a tree species that has been widely used in dendroclimatology and dendrohydrology (Kang et al., 2002; Tian et al., 2007). The dominant tree species at the sampling site appeared healthy and were relatively isolated at and close to their upper limit. The trees grew under poor soil conditions, and the forest stands were rather open. The soils are generally shallow and poor in organic matter (Sheppard et al., 2004). Field measurements and sampling were carried out in June 2012.

\subsection{Tree-ring sampling and data analysis}

Standard 5-mm increment cores were taken from living trees, stumps, and logs. The trees were sampled at breast height with an increment borer. A total of 104 cores or sections were taken from 52 trees within a range of nearly $8.5 \mathrm{~km}$. All cores were mounted, air-dried, sanded, and cross-dated using standard dendrochronological methodology (Stokes and Smiley, 1968). The LINTAB 6 measuring system was used to measure tree-ring widths for all series. The width of each annual tree-ring was measured to the nearest $0.01 \mathrm{~mm}$. The measurements and visual cross-dating underwent quality control using the International Tree-Ring Data Bank software program COFECHA (Holmes, 1983).

The tree-ring-width series were standardized using the program ARSTAN (Cook, 1985). A double-detrending method was used to enhance the climate signal contained in the tree-ring-width series by reducing the noise caused by biological growth trends and endogenous disturbance events (Cook and Kairiukstis, 1990). The initial detrending was completed by fitting an exponential or linear regression curve of any slope to each individual tree-ring-width series. A secondary detrending was accomplished by fitting a cubic spline with a 50\% frequency-response cutoff equal to 67\% of each series length (Cook and Kairiukstis, 1990). After detrending, individual series of each tree were averaged into single tree indices. This detrending method was able to remove long-timescale variance but could retain variance over periods up to a century using these trees. Only the prewhitened residual tree-ring-width series 
were used for further analysis.

The Expressed Population Signal (EPS) statistic was used to determine the change in chronology quality that occurred as sample size varied through time (Wigley et al., 1984; Briffa and Jones, 1990). EPS value was calculated using a 30-year moving window with 15-year overlaps to determine the most suitable parts for climate reconstruction. The tree-ring-width chronology was truncated at the decade interval, in which the running EPS fell below the standard value of 0.85 , as proposed by Wigley et al. (1984).

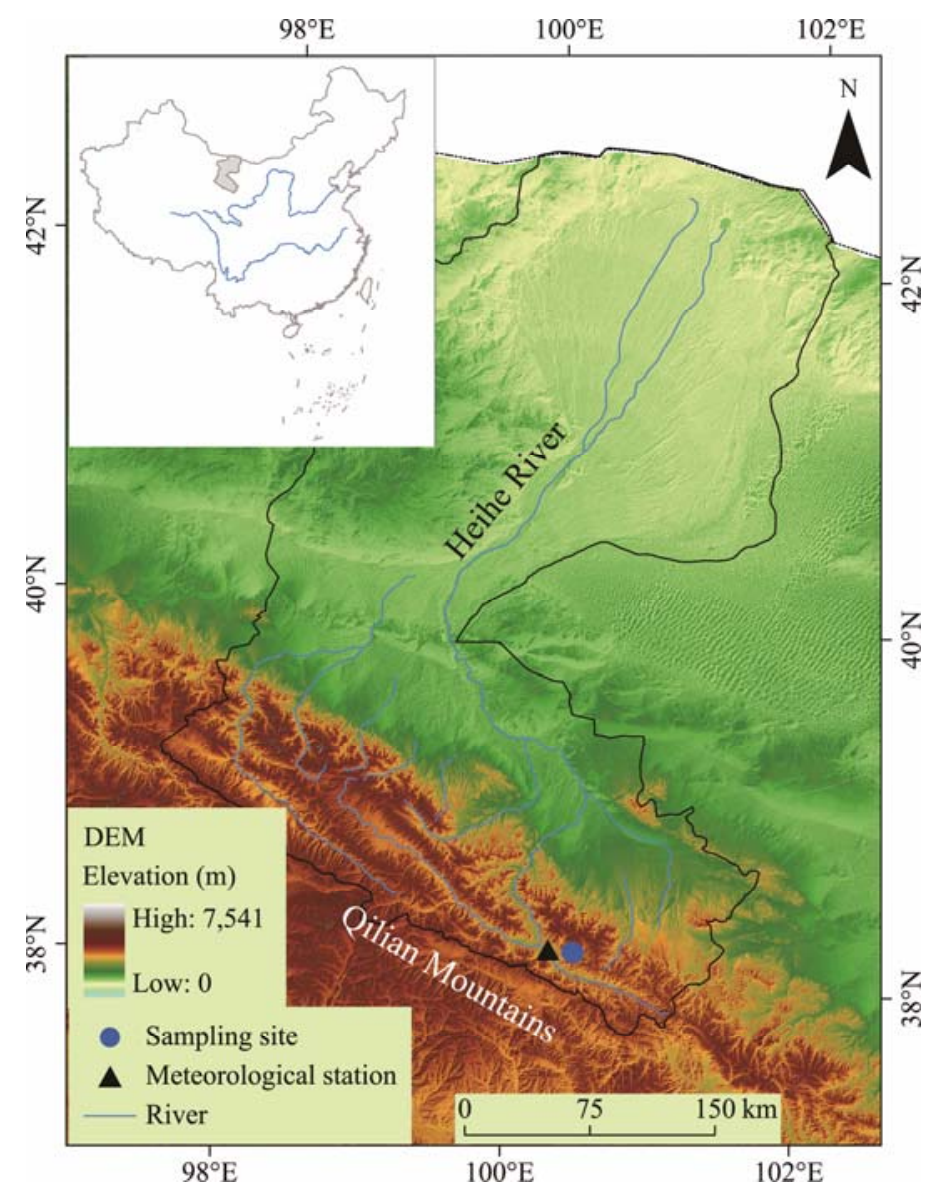

Fig. 1 Locations of the sampling site and the meteorological station

\subsection{Climate data}

The study area is characterized by a semi-arid continental climate and affected by the Tibetan Plateau climate (Liu et al., 2006). The climate in the upper reaches of Heihe River Basin is dominated by westerly flow and partially affected by the southerly monsoon (Wang et al., 2003). Climate data from nearby regional meteorological stations were obtained from the China Meteorological Data Sharing Service System (http://www.escience.gov.cn/metdata/page/index.html). Monthly temperature and precipitation records were obtained from the Qilian Meteorological Station $\left(38^{\circ} 01^{\prime} 08^{\prime \prime} \mathrm{N}, 100^{\circ} 02^{\prime} 05^{\prime \prime} \mathrm{E} ; 2,787.4 \mathrm{~m}\right.$ asl), which was the closest meteorological station (Fig. 1). The annual mean temperature during the period $1961-2011$ was $1.1^{\circ} \mathrm{C}$, with a monthly mean minimum in January and maximum in July. The mean annual precipitation was $405.7 \mathrm{~mm}$, and the precipitation between June and August accounted for $90 \%$ of the annual precipitation (Fig. 2). The annual mean relative humidity was $46.5 \%$, with an equable distribution in each month.

To demonstrate that tree-ring chronology and the climate records reflect large-scale climate variability, we correlated the measured data with the regional monthly gridded climate dataset 
obtained from the high-resolution $0.5^{\circ}$-gridded climate data set CRU TS 3.1 (Mitchell and Jones, 2005). The historical monthly temperature data for the region were defined by grid coordinates $80^{\circ}-120^{\circ} \mathrm{E}$ and $30^{\circ}-50^{\circ} \mathrm{N}$ for the period $1961-2005$. The analyses were achieved using the KNMI climate explorer, a web-based collection of climate data analysis tools maintained by the Royal Netherlands Meteorological Institute (Royal Netherlands Meteorological Institute; http://climexp.knmi.nl).

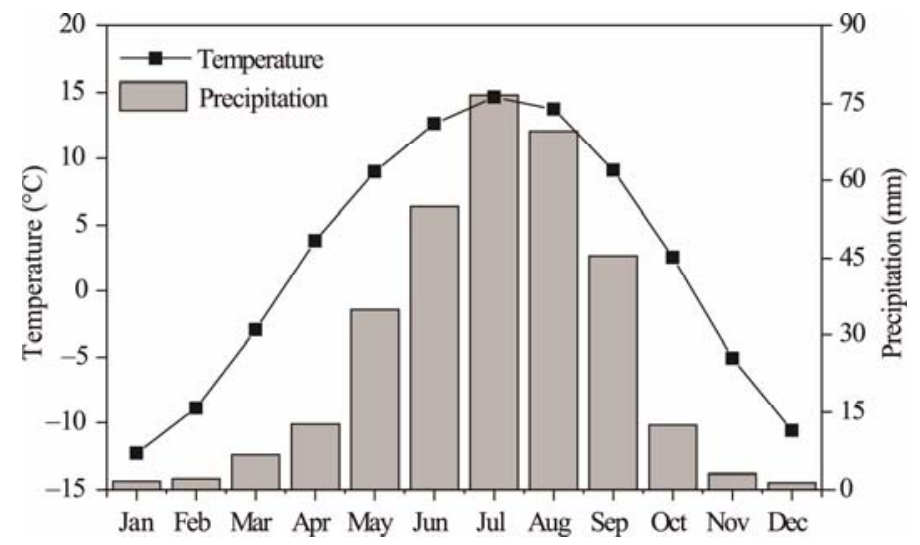

Fig. 2 Monthly mean temperature and monthly precipitation for the Qilian Meteorological Station during the period 1961-2011

\subsection{Analysis methods of climate-growth responses}

Pearson's correlation analysis, bootstrap correlation and bootstrap response function analysis were used to explore the climate-growth relationships between the tree-ring-width indices and the climate factors using Dendroclim 2002 software (Biondi and Waikul, 2004). A 95\% confidence interval was used to determine the statistical significance of the correlations. The tree-ring-width chronologies were compared with a 17-month window of climate data spanning the period from May of the previous year through September of the current growing season. Climate data used for the bootstrap response function and correlation analysis included monthly mean temperature and total monthly precipitation. The tree-ring-width chronologies were also compared with the temperature and precipitation over various multi-month seasons and a full-year scale.

\subsection{Temperature reconstruction and verification methods}

Linear regression models were used to construct the past values of climate variables based on the tree-ring-width chronologies. The reliability of the regression models was evaluated by statistics on calibration and verification periods and by employing leave-one-out cross verification method (Michaelsen, 1987). A split period verification analysis was deemed inappropriate due to the short length of the instrumental climate record (Gordon, 1982; Michaelsen, 1987). The following statistics were used to evaluate the quality of the reconstruction: Pearson correlation coefficient $(r)$, explained variance adjusted for loss of degrees of freedom (adjusted $R^{2}$ ), the reduction of error (RE) statistic for validation, and coefficient of efficiency (CE) (Fritts, 1976; Cook et al., 1999). The values of CE are normally lower than those of RE except that its benchmark for determining model skill is the verification period and not the calibration period, which demonstrated $\mathrm{CE}$ is more rigorous than RE. These tests proved the validity of the regression model. Once the final regression model was successfully validated, it was calibrated on the full instrumental period (1961-2011) used for the final reconstruction model.

\subsection{Multi-taper method spectral analysis}

The variability of the temperature reconstruction in the frequency domain was examined using the multi-taper method (MTM) of spectral analysis (Mann and Lees, 1996). MTM is non-parametric. It uses a series of tapers that reduce the variance of spectral estimates, which is an advantage over other spectral window methods (Percival and Walden, 1993). 


\section{Results}

\subsection{Tree-ring chronology}

Ninety-two ring-width series from 46 individual trees were included in the final analysis (Table 1). The mean sensitivity, which is a measure of the relative differences in width between adjacent tree-rings, was 0.30. The first order auto-correlation was 0.65, suggesting that Qilian juniper tree-ring growth in one year influenced its growth in the following year. The average correlation among tree-ring series was 0.72 , indicating that the tree-ring chronology contained common growth-limiting signals, most likely the large-scale climate signal. The chronology spanned the period from 1395 to 2011 (Fig. 3). Based on EPS statistics (Wigley et al., 1984), the chronology was considered reliable when the sample size exceeded 7 cores, corresponding to the period from 1445 to 2011 . The mean segment length of the chronology was 566 years, indicating its ability to resolve interannual- to interdecadal-scale tree growth variations that are likely related to climate change (Cook et al., 1994).

Table 1 Statistics for the residual tree-ring-width chronology

\begin{tabular}{lc}
\hline Statistical item & Standard dendrochronological (STD) \\
\hline Mean sensitivity & 0.303 \\
Standard deviation & 0.171 \\
First-order autocorrelation & 0.650 \\
Mean correlations among all series & 0.720 \\
Mean correlations between trees & 0.529 \\
Expressed population signal (EPS) & 0.980 \\
\hline First year where EPS $>0.85$ (No. of cores) & $1,445(7)$ \\
\hline
\end{tabular}

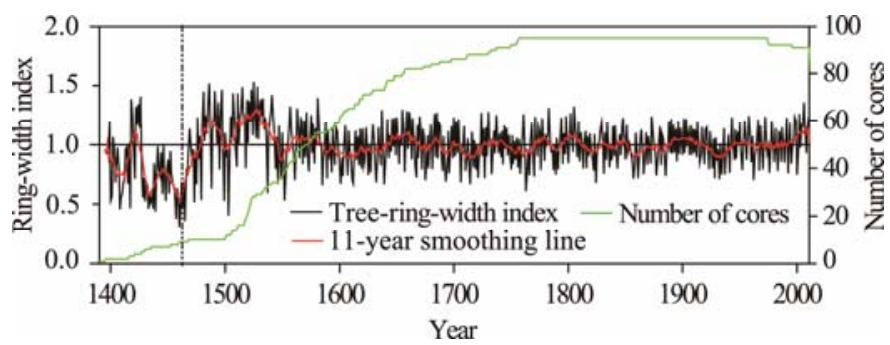

Fig. 3 Standard tree-ring-width chronology and sample size of Qilian juniper in the middle Qilian Mountains (the red curve superimposed on the tree-ring-width indices is an 11-year smoothing line) from 1395 to 2011

\subsection{Climate-growth relationship}

Consistent relationships between tree growth and climate variables (monthly average temperature and precipitation) through time and across plots are shown in Fig. 4. The relationship between tree-ring-width and temperature showed a positive correlation, while the correlations between tree-ring-width and monthly precipitation totals were relatively weak. All temperatures were associated with positive growth responses except in the previous August. Correlation analysis results demonstrated that temperature is the limiting climate factor most strongly associated with tree growth at the upper tree line. Significant positive correlations $(P<0.05)$ with temperature in May $(r=0.302)$ and September $(r=0.323)$ of the previous year were weaker, and those in January, February, March, April, June, July, and August of the current year were higher ( $r$ values from 0.486 to 0.598$)$. The highest correlation was found between tree ring and annual mean temperature $(r=0.641, P<0.001)$. Therefore, annual temperature was used as the climate variable for reconstruction. 

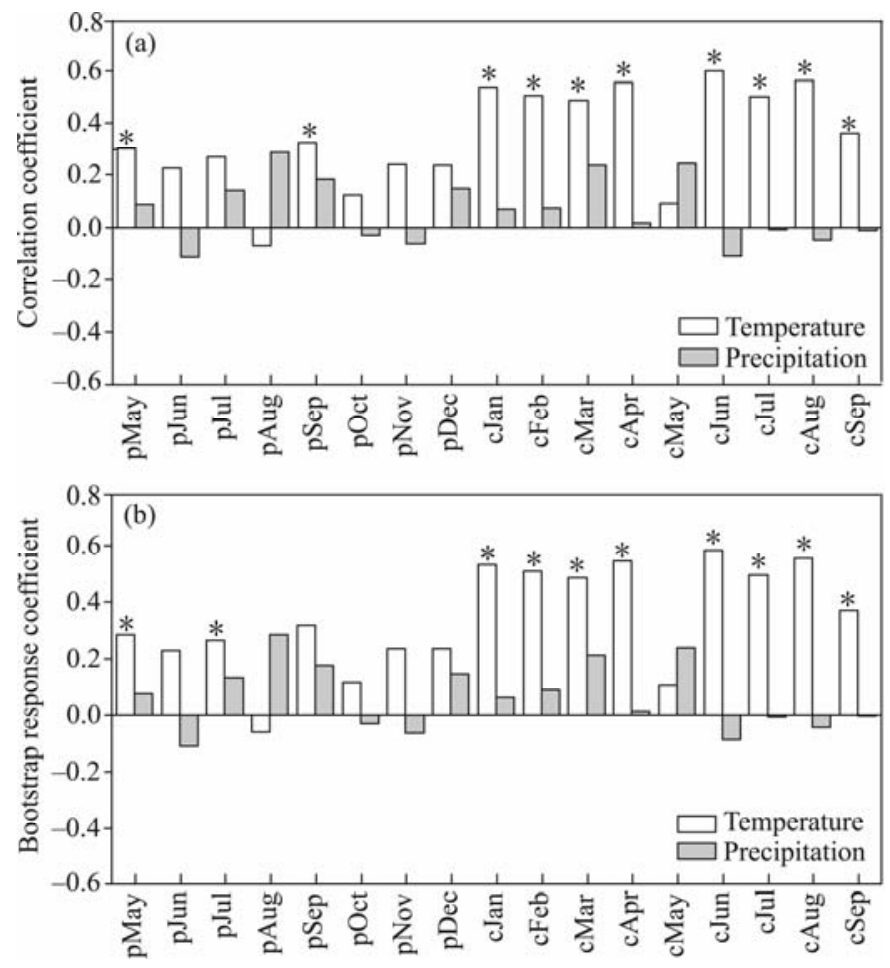

Fig. 4 Correlation coefficient (a) and bootstrap response coefficient (b) of standard chronology with mean temperature and precipitation measured at the Qilian Meteorological Station from 1961-2011. The prefix "p" and "c" in horizontal axis denotes previous year and current year, respectively. The asterisks indicate significant correlation at the $95 \%$ confidence level.

\subsection{Temperature reconstruction}

Basing on the results of the growth-climate analysis, we used a simple linear regression function to reconstruct annual mean temperature for the upper reaches of Heihe River Basin: $\mathrm{T}=$ $-0.673+2.689 \mathrm{~W}$. Where $\mathrm{T}$ is the annual mean temperature and $W$ is the tree-ring index.

Reconstruction accounted for $57.8 \%$ (Fig. 5a) of the actual temperature variance over the common calibration period (1961-2011) of the tree-ring chronology and temperature data. The reconstructed temperatures closely matched the instrumental record. Although the explained variance is not very high, low-frequency as well as high-frequency temperature variations were adequately captured by the reconstruction. It is seen that the significant increase during 1961-2011 recorded in observed instrumental temperatures were captured by estimated values derived by the reconstruction model. The reconstruction closely tracks the observed temperatures (Fig. 5b) and the decreasing sensitivity to temperature. All the values of $R^{2}, R_{\mathrm{adj}}{ }^{2}, F$, and $P$ in Table 2 are quite close to the values of the original dataset. These indicated that the regression model was stable and reliable during the calibration period. The validation results showed that the reconstruction was reliable because $\mathrm{RE}$ and $\mathrm{CE}$ had positive values and the values of CE normally were lower than those of RE. Correlation coefficients for the split-sample validation periods were also large and significant, exceeding the $99 \%$ confidence level. These results demonstrated the reliability of the regression model.

The annual mean temperature in the study area for the 1395-2011 period was then reconstructed based on the above model (Fig. 5c). Because the EPS value of the tree-ring chronology was above 0.85 for the period 1445-2011, the reconstructed temperature for this period should be interpreted. The annual mean temperature for the $1445-2011$ period is $0.99^{\circ} \mathrm{C}$, with a standard deviation of $0.21^{\circ} \mathrm{C}$. The reconstructed temperature series for the last 566 years showed annual to multi-year fluctuations punctuated with cool and warm periods. In the warm-cold criteria of mean $\pm \mathrm{SD}$, the mean value for "cold" is less than $0.78^{\circ} \mathrm{C}$, and the mean 
value for "warm" is more than $1.2^{\circ} \mathrm{C}$. There were 85 cold years $(15.02 \%), 88$ warm years $(15.55 \%)$, and 393 normal years $(69.43 \%)$ defined during the entire period.

Table 2 Statistics of different calibration and verification periods for the regression model

\begin{tabular}{lccccc}
\hline & $\begin{array}{c}\text { Calibration } \\
(1961-1986)\end{array}$ & $\begin{array}{c}\text { Verification } \\
(1987-2011)\end{array}$ & $\begin{array}{c}\text { Calibration } \\
(1982-2011)\end{array}$ & $\begin{array}{c}\text { Verification } \\
(1961-1981)\end{array}$ & $\begin{array}{c}\text { Full calibration } \\
(1961-2011)\end{array}$ \\
\hline$R^{2}$ & 0.61 & 0.57 & 0.53 & 0.57 & 0.578 \\
$R_{\text {adj }}^{2}$ & 0.59 & 0.56 & 0.50 & 0.56 & 0.569 \\
$F$ & & & & & 15.12 \\
$P$ & & & & & 0.001 \\
$\mathrm{RE}$ & 0.84 & & 0.81 & $0.58 \mathrm{~L}$ \\
$\mathrm{CE}$ & & 0.42 & & 0.37 & 0.58 \\
\hline
\end{tabular}

Note: $R^{2}$, variance explained by the regression model; $R_{\text {adj }}{ }^{2}$ (adjusted $R^{2}$ ), variance explained adjusted for loss of degrees of freedom; $F$, $F$ statistic for the statistical significance of the regression models; $P, P$-value is a function of the observed sample results (a statistic) that is used for testing a statistical hypothesis; RE, reduction of error statistic; CE, coefficient of efficiency; L, the leave-one-out verification.
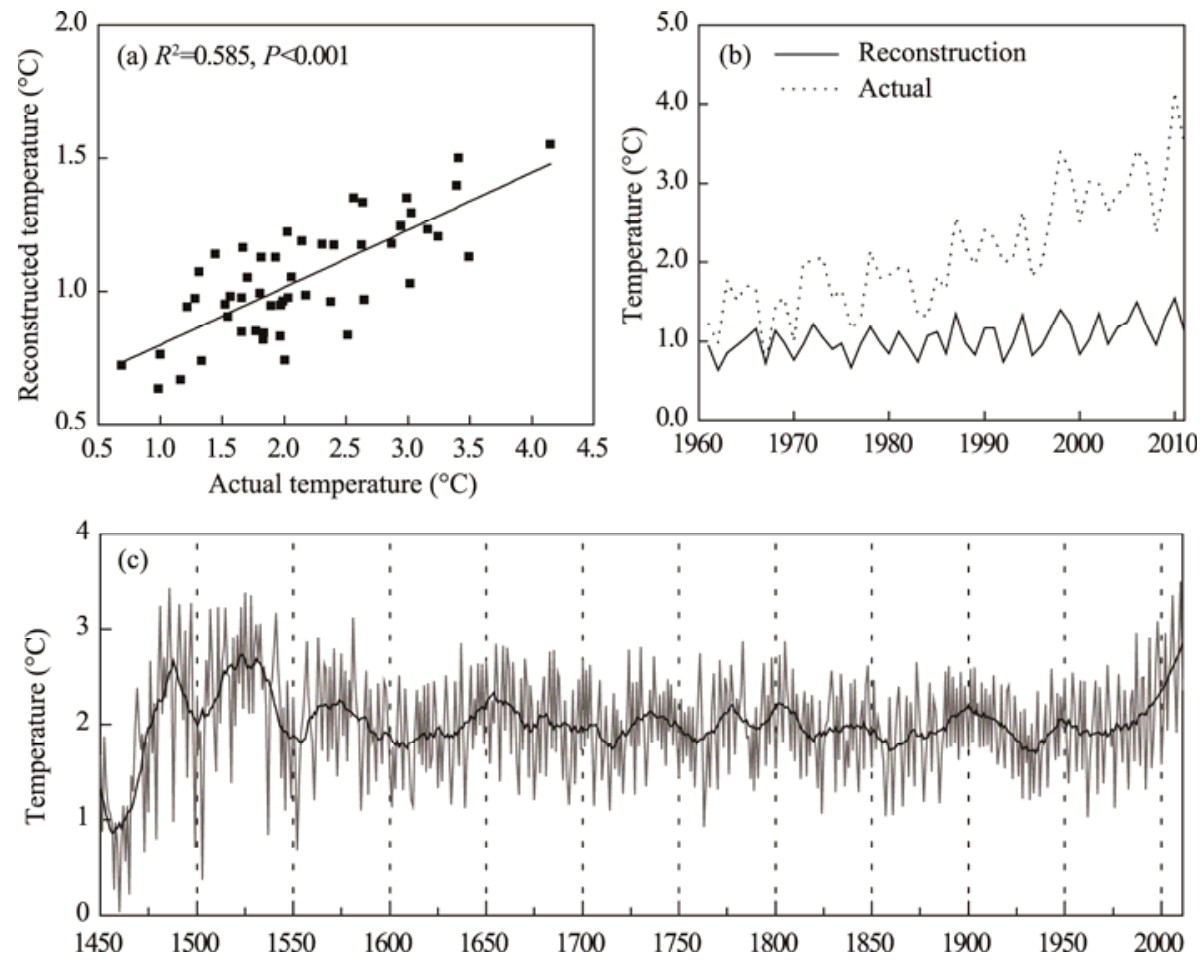

Fig. 5 Correlation of actual and reconstructed annual mean temperatures during the period of 1961-2011 (a); comparison of actual and reconstructed annual mean temperatures from 1961 to 2011 (b); tree-ring reconstruction of annual mean temperature, plotted annually (thin line) from 1462 to 2011, along with a smoothed 11-year moving average (thick line) (c).

Reconstruction of the annual mean temperature revealed lower temperatures from 1445 to 1482 , followed by a warmer period from 1483 to 1567 . There has been a general cooling trend since 1540 s, with pronounced cooling from 1570 to 1890 . Although punctuated by a slim cold interval since 1540 s, a persistently warm episode occurred in $1640 \mathrm{~s}-1670 \mathrm{~s}$, which lasted about 30 years and was the most notable warm anomaly in the reconstruction. During the last warm period (from 1987 to present), the temperatures for all the years were above the long-term mean. The $20^{\text {th }}$ century is the warmest hundred years (mean temperature $(\mathrm{Tem})=1.97^{\circ} \mathrm{C}$ ), and $1990-2011$ was the warmest period $\left(\mathrm{Tem}=2.41^{\circ} \mathrm{C}\right)$ during the past 566 years. The warmest 100 - and 10 -year periods before the $20^{\text {th }}$ century were $1480-1570 \quad\left(\mathrm{Tem}=2.29^{\circ} \mathrm{C}\right)$ and $1650-1660 \quad\left(\mathrm{Tem}=2.23^{\circ} \mathrm{C}\right)$, 
respectively, and the coldest 100 - and 10 -year periods were $1800-1899\left(\mathrm{Tem}=1.95^{\circ} \mathrm{C}\right)$ and 1642-1651 $\left(\mathrm{Tem}=1.92^{\circ} \mathrm{C}\right)$, respectively. After a 30-year moving average, the reconstruction showed that the cold and warm intervals appeared to be alternative on a decadal scale. Several cold episodes occurred during 1450s-1480s, 1590s-1770s, 1810s-1890s, 1920s-1940s, and 1960s-1970s. Marked periods with high temperatures occurred during 1490s-1580s, $1780 \mathrm{~s}-1800 \mathrm{~s}, 1900 \mathrm{~s}-1910 \mathrm{~s}, 1950 \mathrm{~s}$, and $1980 \mathrm{~s}$ to present. The years that had five top high-temperature extremes (anomaly $\geq 2$ STD) were 1486, 1525, 1528, 2006, and 2010. The reconstructed temperature had five cold extremes in 1763, 1824, 1857, 1861, and 1962.

\subsection{Spatial representativeness of the reconstructed temperature}

To demonstrate that our reconstruction and instrumental records reflected regional-scale temperature variability, we correlated these data with the CRUts 3.1 dataset (Mitchell and Jones, 2005). The reconstructed temperature was significantly correlated with the annual mean temperature over large areas of the upper reaches of Heihe River Basin (Fig. 6a). It is demonstrated that the highest correlation coefficents were concentrated mainly in the upper reaches. Although correlations were lower for the actual temperature, the spatial pattern of the correlation is quite similar to that of the instrument-recorded data (Fig. 6b). The results showed significant correlations with gridded climatic variables on a regional scale, indicating that the reconstruction represents climatic variations for an extended area surrounding the sampling sites, and even a larger territory in northeastern Tibetan Plateau. The annual mean temperature reconstruction in the upper reaches of Heihe River Basin can also provide base data for historical droughts analysis, water resources planning, and management in the arid inland drainage basin or even to a greater extent.
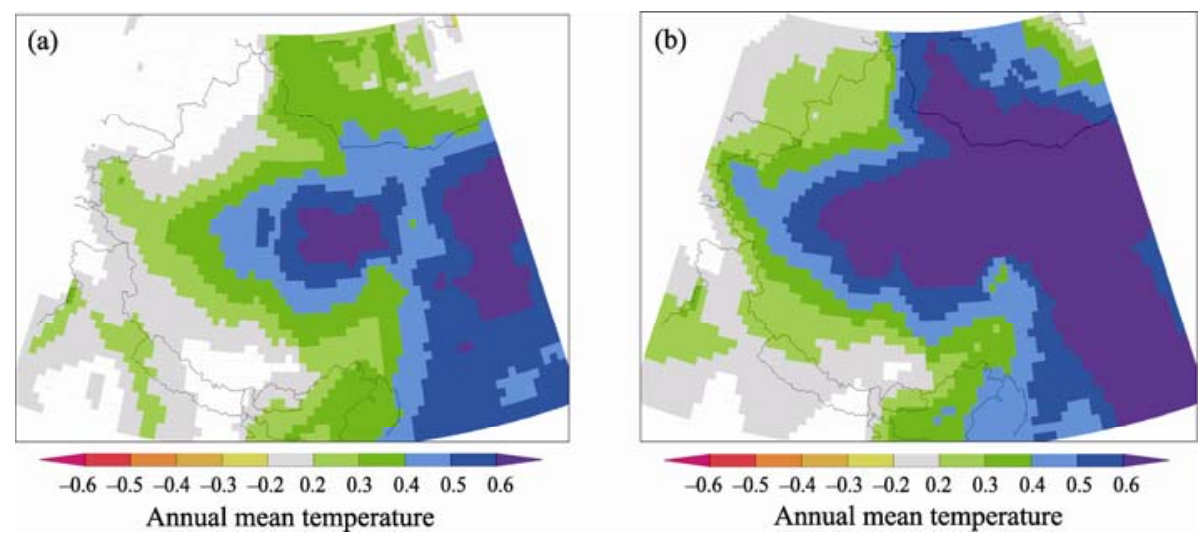

Fig. 6 Spatial correlations of reconstructed (a) and instrument-recorded (b) annual mean temperatures with the concurrent CRU3.1 land temperature grid dataset over their overlapping periods for the period 1961-2005

\section{Discussion}

\subsection{Growth-climate response}

Tree growth-climate relationship analysis indicated that except August of the previous year, all the temperatures in the other months had positive correlations with tree-ring data. Qilian juniper ring-width chronologies from the upper timberline were sensitive to temperature, especially in the summer season (June to September of the current year) and the winter and spring seasons (January to April of the current year) (Fig. 2). This has also been reported for other high-elevation conifers from the same area (Liu et al., 2005) and other areas, such as west Sichuan (Shao and Fan, 1999) and the eastern Tibetan Plateau (Bräuning, 2001; Gou et al., 2007; Liang et al., 2008). The strong influence of temperatures during the winter preceding tree growth is a common feature in high-altitude tree-ring series (Liu et al., 2005; Liang et al., 2006; Zhang and Qiu, 2007). This is generally explained by a shorter vegetation period after a cold winter due to the delayed melting 
of soil ice and the delayed warming of the soil until temperatures of $>5^{\circ} \mathrm{C}$ are reached, which are needed for physiological root activity, or by damage to the photosynthetic active plant mass by extremely low temperatures (Körner, 1998). The positive correlation with spring temperature is reasonable due to the fact that high temperatures in the spring season of the growth year favour the formation of early wood cells, which account for the majority of the total tree-ring width (Yang et al., 2010). At the timberline, conifer tracheids divide and enlarge during the warmest period of the growing season when a minimum temperature is a critical factor affecting cambium activity (Deslauriers et al., 2003). Phenologically, early spring is when bud germination and cell production occur and late autumn is when the growing period ends. Temperatures in spring and autumn determine the length of the growing period and the growth increment of the current year. Temperature and light are more important limiting factors than precipitation when precipitation is sufficient and the evaporation rate is low, especially in permafrost areas (Zhang et al., 2011). Low June and July minimum temperatures can even cause the formation of frost rings and missing rings as observed at the northern timberline in Obsko-Tazovskaya forest-tundra (Gurskaya and Shiyatov, 2006). Warm conditions in the late autumn might increase carbohydrate storages in the stem, and thus enhance earlywood growth in the following spring (Gou et al., 2008). However, winter temperatures have been found to constrain radial growth in different temperate species and ecosystems in eastern North America (Pederson et al., 2004). The warmer winters in regions without a regular snow pack may experience increased tree growth and carbon uptake (Groffman et al., 2001). Defoliation and bud mortality would deplete an important pool of stored carbon and reduce a tree's potential for future growth and photosynthetic capture (Lazarus et al., 2004; Misson et al., 2004). Climatic conditions of the previous year may precondition physiological processes within the tree and hence strongly influence tree growth (Bradley, 1985). Besides these, there are other non-climatic factors that may exert an influence, such as competition, defoliators and soil nutrient characteristics.

\subsection{Comparison with other temperature reconstructions}

To further assess the validity of our temperature reconstruction for the upper reaches of Heihe River Basin, we compared it to other temperature reconstructions from the surrounding regions within the eastern Tibetan Plateau (Fig. 1). The reconstruction was most similar to the December-April temperature reconstruction based on stable carbon isotope $\left(\delta^{13} \mathrm{C}\right)$ for the middle Qilian Mountains, about $52 \mathrm{~km}$ northeast of the sampling site (Fig. 7; Liu et al., 2005). For meeting the replication criterion, the two series were truncated after 1450. The two reconstructions are in good agreement with each other at the same timescales. They both fluctuated at a relatively low temperature level during the middle $15^{\text {th }}$ century, and were warm during the period of the later $15^{\text {th }}$ through $16^{\text {th }}$ centuries. Since the $16^{\text {th }}$ century, temperature fluctuation shows low values until the late $19^{\text {th }}$ century. Temperature is relatively warm in the recent hundred years. The cold episodes found in this study, namely in $1450 \mathrm{~s}-1480 \mathrm{~s}, 1590 \mathrm{~s}-1770 \mathrm{~s}, 1810 \mathrm{~s}-1890 \mathrm{~s}, 1920 \mathrm{~s}-1940 \mathrm{~s}$, and $1960 \mathrm{~s}-1970 \mathrm{~s}$ were in agreement with cold periods that occurred during 1440s-1500s and 1580s-1880s in the upper reaches of Heihe River Basin. The warm episodes in 1900s-1910s, 1950s, and 1980s-2011 prominent in this series matched with the warm period of 1900-2000 in the upper reaches of Heihe River Basin. However, there are some discrepancies between the two reconstructions, possibly due to the different seasonal responses of the tree-ring data used in different reconstructions.

Reconstruction preserved the inter-annual to multi-decadal annual temperature variability (Fig. 7). The temperature reconstruction from this study has several warm/cold periods that are also reflected in other tree-rings and retreat of glaciers. Cold periods such as $1590 \mathrm{~s}-1770 \mathrm{~s}$ and 1810 s-1890s denoted in the present study agreed reasonably well with cold temperatures measured in the northeast Tibetan Plateau (Kang et al., 2000; Liu et al., 2005; Zhang and Qiu, 2007; Zhu et al., 2008). The most severe cold periods in other tree-ring-based temperature reconstructions correspond well to the cold/warm periods indicated here, particularly 1850s-1860s (Liu et al., 2006; Fan et al., 2009; Cai et al., 2010; Zhang et al., 2011). The extended cold episodes noted here in around 1800-1850, 1890-1930, and 1965-1995 are contemporaneous with cooling in nearly all other regions of the eastern Tibetan Plateau despite the seasonal 
differences in the various temperature reconstructions, although some differences can be seen in the amplitude, persistence, and phases of cooling. Decreasing trends in tree-ring width were also detected in the winter-half-year temperature of eastern China during the periods 1750-1816 and 1863-1932 (Ge et al., 2003). Other short regional cold conditions in around 1625, 1685, and 1760 occurred synchronously in each parts of the eastern Tibetan Plateau. Two extended cold periods were found from the 1590 s to 1770 s and from 1810 s to 1890 s, and occurred during the Little Ice Age $\left(16^{\text {th }}\right.$-mid $19^{\text {th }}$ century) (Mann et al., 1999; Mann, 2002). Specifically, the period of 1923-1947 was a low-temperature period, which caused widespread damage to natural vegetation and agriculture in eastern Qinghai province and Hexi region of Gansu province (Yuan, 1994). Frost disasters were derived from the Qilian Mountains, and pointed to the necessity of considering large temperature fluctuations during the crucial spring transitional period as a real threat to terrestrial ecosystem structure and functioning ability (Gou et al., 2005).

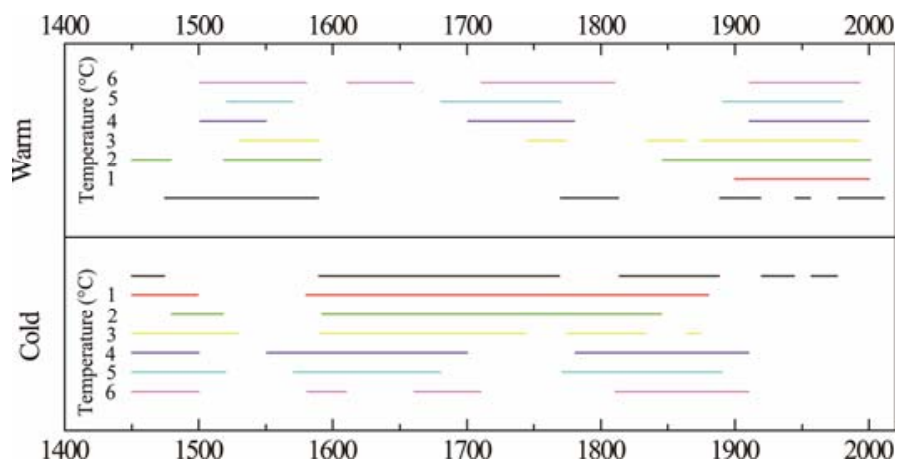

Fig. 7 Duration of warm and cold periods in the surrounding and other areas in different proxies. The black bars denote this study. Numerals 1-6 denote the mean temperatures from Qilian Mountains (December-April; Liu et al., 2005), Halihatu National Forest Park (September-April; Zhu et al., 2008), the Dulan region (Kang et al., 2000), eastern China (winter-half-year; Ge et al., 2003), Dunde ice-core ( $\delta^{18} \mathrm{O}$; Yao et al., 1991), and the Northern Hemisphere (annual mean; Mann et al., 1999), respectively.

The warm periods $1490 \mathrm{~s}-1580 \mathrm{~s}, 1900 \mathrm{~s}-1910 \mathrm{~s}, 1950 \mathrm{~s}$, and $1980 \mathrm{~s}-2011$ are in good agreement with compared records. The longest warm period from 1978 to 2011 is not local and has regional characteristics consistent with widespread warming (Jacoby et al., 1996, 2003; Liu et al., 2006; Wang et al., 2007; Fan et al., 2009; Sano et al., 2009; Zhu et al., 2009; Cai et al., 2010; Chen et al., 2010; Zhang et al., 2011). There is little agreement between our reconstruction and the Qamdo area (Zhu et al., 2011) during 1501-1514 and 1794-1804 periods. 1930-1960 is likely the warmest period in the last few centuries as seen in the tree-ring records, and was notable throughout the $20^{\text {th }}$ century over China, especially in the southwestern part of China and on the Tibetan Plateau (Wang et al., 2004). The warming period from 1930-1960 was also detected in North Tibet, as reflected by $\delta^{18} \mathrm{O}$ ice core records (Thompson et al., 2006; Wang, 2006; Yao et al., 2006; Kang et al., 2007), from northwestern Sichuan province of South China (Shao and Fan, 1999), East China and West China (Yang et al., 2002; Ge et al., 2003; Tan et al., 2003; Wang, 2006), and as recorded in temperature composites in the central and western Himalaya (Cook et al., 2003; Yadav et al., 2004).

However, this temperature reconstruction differed from other temperature records for the beginning and end of the change phases, as well as in the magnitudes of fluctuations, whereas they showed similar variations in warm or cold phases. This discrepancy most likely reflects the different sampling sites and local microclimate influence, the use of different instrument-recorded data, and the different calibration periods (He et al., 2013). Slightly different seasonality (Frank and Esper, 2005) and inconsistent variability between the mean, maximum, and minimum temperatures (Wilson and Luckman, 2003; Luckman and Wilson, 2005) also prevent an adequate estimation of the long-term absolute temperature amplitude. A more complete understanding of the spatial and temporal characteristics of annual temperature variability at the upper reaches of the Heihe River Basin requires more tree-ring records sensitive to annual temperatures. 


\subsection{Multi-taper method spectral analysis}

Multi-taper method (MTM) spectral analysis was employed to examine the characteristics of temperature variability in the frequency domain (Mann and Lees, 1996). The results of the spectral analysis of MTM was performed over the full range of the reconstruction from 1445 to 2011 (Fig. 8). The MTM analysis revealed peaks at 85.7, 75.1, 46.1, 32.9, 8.1, 3.6, 2.9, and 2.1 years $(P<0.01)$, and at 11.2 and 5.1 years $(P<0.05)$. The MTM results indicated the existence of several important cycles for regional temperature variability. The 85.7-year mode was most significant in this reconstruction, which resembled other reconstructed temperature series (D'Arrigo et al., 2003, 2005) and suggested an influence of solar forcing (Pederson et al., 2001). One noteworthy feature of this reconstruction was that the warm episodes in $1780 \mathrm{~s}-1800 \mathrm{~s}$ and 1900s-1910s were in general agreement with the Dalton (1790-1820) and Damon (1890s-1920s) periods of low solar irradiance (Eddy, 1976). This phenomenon demonstrated the possible association between annual temperature variation in this study area and solar activity. The significant cycle at 36.6 and 28.5 years might be linked to the Pacific Decadal Oscillation (PDO, http://ds.data.jma.go.jp/tcc/tcc/products/elnino/decadal/pdo.html) (Mantua et al., 1997), and our analyses indicated a negative correlation $(r=-0.15, P<0.01)$ between the reconstruction and the mean annual PDO index of Mantua et al. (1997) from 1900-2011. This result is consistent with the hypothesis that a large-scale Asian tree-ring network may be able to reflect PDO signals (D'Arrigo et al., 2006). The PDO has wide-ranging impacts on global climate and marine ecosystems on a decadal time scale (Mantua et al., 1997; Mantua and Hare, 2002). In addition, as the decadal background, it can modulate seasonal and interannual climate variability. The PDO time scale is set by the baroclinic Rossby wave speed (ocean adjustment process). Under global warming, ocean stratification would enhance, Rossby waves would speed up, and the interannual and decadal variability periods might become shorter (Saenko, 2006). Significant spectral peaks were also found at 8.1, 3.6, 2.9, and 2.1 years, which fall within the "classical" ENSO (El Niño-Southern Oscillation) band of 2-8 years (Allan et al., 1996; Li et al., 2012). These high-frequency cycles may suggest teleconnections of local temperature variability with tropical ocean-atmosphere systems.

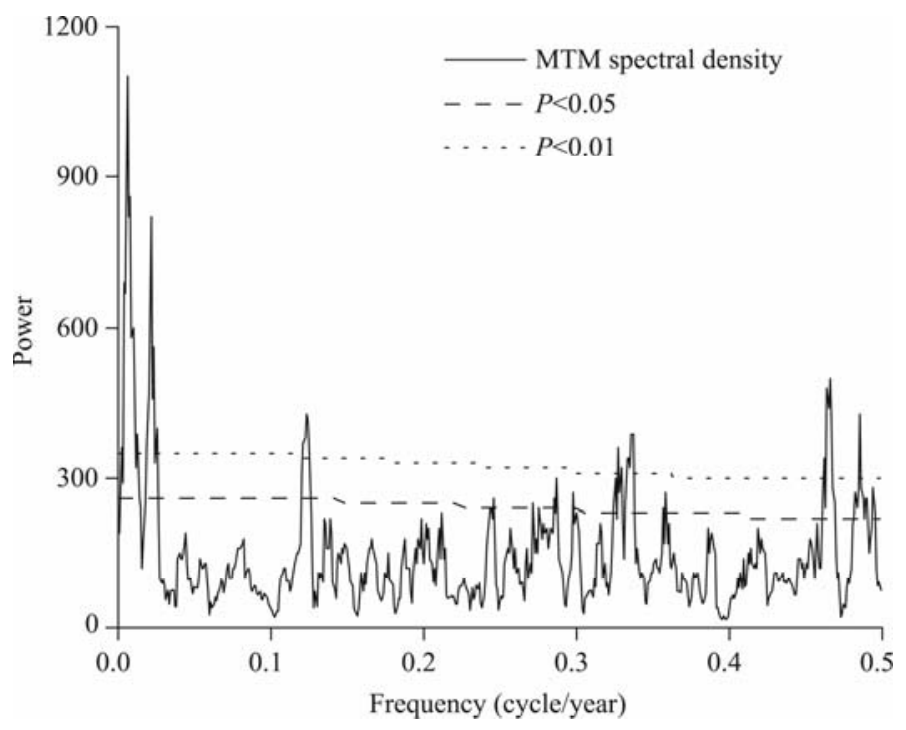

Fig. 8 Results of MTM spectral analysis of the temperature reconstruction

\section{Conclusions}

A tree-ring width chronology from 1395 to 2011 was developed using 92 tree-ring cores in the upper reaches of Heihe River Basin in Northwest China. The chronology was most reliable after 
1445, for the period in which EPS equals 0.85. The relationships between tree-ring widths of Qilian juniper at the upper tree-line limit and climate variables were analyzed, and the tree-ring width chronology in the upper forest limit appears to be mainly induced by regional annual mean temperature variability. The result proved that the strong influence of temperatures during tree growth is a common feature in high-altitude tree-ring series. Such results suggest a more cautious approach while using tree-ring chronology to reconstruct local or regional climate history. Based on the tree growth-climate relationship, the annual mean temperature before growing season since 1445 was reconstructed for the upper reaches of the Heihe River Basin. The $20^{\text {th }}$ century was the warmest 100 years within the time period studied, while the coldest 100 -year and decadal periods occurred in $1490 \mathrm{~s}-1580 \mathrm{~s}$ and $1780 \mathrm{~s}-1800 \mathrm{~s}$, respectively. The recovered temperature history agrees well with other temperature series reconstructed across the northeastern Tibetan Plateau, demonstrating that this reconstructed temperature could be used to evaluate regional climate change. Because the reconstruction is only based on one site of trees, it is very likely that the reconstruction contains site-specified variations. More tree-ring sites and longer chronologies are needed to acquire an accurate and thorough representation of climate variations spatially. The annual mean temperature analysis in this paper suggests that the water resources policy in the Heihe River Basin should be based not only on short-term instrumental records but also on long-term records for regional water resources management. Long-term perspectives on climatic variations should be considered by policy makers.

\section{Acknowledgements}

This study was supported by the National Natural Science Foundation of China (91025002, 30970492), the National Key Technology Research \& Development Program (2012BAC08B05), and the Key Project of the Chinese Academy of Sciences (KZZD-EW-04-05). The authors are grateful to the editors and the two anonymous reviewers for their invaluable comments.

\section{References}

Allan R J, Lindesay J, Parker D E. 1996. El Niño-Southern Oscillation and Climatic Variability. Collingwood, Australia: CSIRO, 118-126.

Biondi F, Waikul K. 2004. DENDROCLIM2002: A C++ program for statistical calibration of climate signals in tree ring chronologies. Computers \& Geosciences, 30(3): 303-311.

Bradley R S. 1985. Quaternary Paleoclimatology: Methods of Paleoclimatic Reconstruction. Boston: Allen and Unwin, 472.

Bräuning A. 2001. Climate history of the Tibetan Plateau during the last 1000 years derived from a network of Juniper chronologies. Dendrochronologia, 19(1): 127-137.

Briffa K R, Jones P D. 1990. Basic chronology statistics and assessment. In: Cook E R, Kairiukstis L A. Methods of Dendrochronology: Applications in the Environmental Sciences. Dordrecht: Kluwer Academic Publishers, $137-152$.

Cai Q F, Liu Y, Bao G, et al. 2010. Tree-ring-based May-July mean temperature history for Lüliang Mountains, China, since 1836. Chinese Science Bulletin, 55(26): 3008-3014.

Chen F, Yuan Y J, Wei W S. 2011. Climatic response of Picea crassifolia tree-ring parameters and precipitation reconstruction in the western Qilian Mountains, China. Journal of Arid Environments, 75(11): 1121-1128.

Chen Y N, Xu C C, Chen Y P, et al. 2010. Response of glacial-lake outburst floods to climate change in the Yarkant River basin on northern slope of Karakoram Mountains, China. Quaternary International, 226(1-2): 75-81.

Cook E R. 1985. A time series analysis approach to tree ring standardization. PhD Dissertation. Tucson: University of Arizona.

Cook E R, Kairiukstis L A. 1990. Methods of Dendrochronology: Applications in the Environmental Sciences. New York: Springer Science \& Business Media, 23-283.

Cook E R, Briffa K R, Jones P D. 1994. Spatial regression methods in dendroclimatology: a review and comparison of two techniques. International Journal of Climatology, 14(4): 379-402.

Cook E R, Meko D M, Stahle D W, et al. 1999. Drought reconstructions for the continental United States. Journal of Climate, 12(4): 1145-1162.

Cook E R, Krusic P J, Jones P D. 2003. Dendroclimatic signals in long tree-ring chronologies from the Himalayas of Nepal. International Journal of Climatology, 23(7): 707-732.

Cook E R, Anchukaitis K J, Buckley B M, et al. 2010. Asian monsoon failure and megadrought during the last millennium. 
Science, 328(5977): 486-489.

D’Arrigo R, Buckley B, Kaplan S, et al. 2003. Interannual to multidecadal modes of Labrador climate variability inferred from tree rings. Climate Dynamics, 20(2-3): 219-228.

D’Arrigo R, Mashig E, Frank D, et al. 2005. Temperature variability over the past millennium inferred from Northwestern Alaska tree rings. Climate Dynamics, 24(2-3): 227-236.

D'Arrigo R, Wilson R, Jacoby G. 2006. On the long-term context for late twentieth century warming. Journal of Geophysical Research: Atmospheres (1984-2012), 111(D3): D03103.

Davi N, Jacoby G, Fang K Y, et al. 2010. Reconstructing drought variability for Mongolia based on a large-scale tree ring network: 1520-1993. Journal of Geophysical Research: Atmospheres (1984-2012), 115(D22): D22103.

Deslauriers A, Morin H, Begin Y. 2003. Cellular phenology of annual ring formation of Abies balsamea in the Quebec boreal forest (Canada). Canadian Journal of Forest Research, 33(2): 190-200.

Eddy J A. 1976. The Maunder minimum. Science, 192(4245): 1189-1202.

Fan Z X, Bräuning A, Yang B, et al. 2009. Tree ring density-based summer temperature reconstruction for the central Hengduan Mountains in Southern China. Global and Planetary Change, 65(1-2): 1-11.

Frank D, Esper J. 2005. Temperature reconstructions and comparisons with instrumental data from a tree-ring network for the European Alps. International Journal of Climatology, 25(11): 1437-1454.

Fritts H C. 1976. Tree Rings and Climate. San Francisco: Academic Press, 207-503.

Ge Q S, Zheng J Y, Fang X Q, et al. 2003. Winter half-year temperature reconstruction for the middle and lower reaches of the Yellow River and Yangtze River, China, during the past 2000 years. Holocene, 13(6): 933-940.

Glickman S T. 2000. Glossary of Meteorology (2 ${ }^{\text {nd }}$ ed.). Boston: American Meteorological Society, 139-174.

Gong D Y, Wang S W. 2000. Influence of atmospheric oscillations on northern hemispheric temperature. Geographical Research, 18(2): 31-38. (in Chinese)

Gordon G A. 1982. Verification of dendroclimatic reconstructions. In: Hughes M K, Kelly P M, Pilcher J R, et al. Climate from Tree Rings. Cambridge: Cambridge University Press, 115-132.

Gou X H, Chen F H, Yang M X, et al. 2005. Climatic response of thick leaf spruce (Picea crassifolia) tree-ring width at different elevations over Qilian Mountains, northwestern China. Journal of Arid Environments, 61(4): 513-524.

Gou X H, Chen F H, Jacoby G, et al. 2007. Rapid tree growth with respect to the last 400 years in response to climate warming, northeastern Tibetan Plateau. International Journal of Climatology, 27(11): 1497-1503.

Gou X H, Chen F H, Yang M X, et al. 2008. Asymmetric variability between maximum and minimum temperatures in Northeastern Tibetan Plateau: evidence from tree rings. Science in China Series D: Earth Sciences, 51(1): 41-55.

Groffman P M, Driscoll C T, Fahey T J, et al. 2001. Colder soils in a warmer world: a snow manipulation study in a northern hardwood forest ecosystem. Biogeochemistry, 56(2): 135-150.

Gurskaya M A, Shiyatov S G. 2006. Distribution of frost injuries in the wood of conifers. Russian Journal of Ecology, 37(1): $7-12$.

He M H, Yang B, Datsenko N M. 2013. A six hundred-year annual minimum temperature history for the central Tibetan Plateau derived from tree-ring width series. Climate Dynamics, 43(3-4): 641-655.

Holmes R L. 1983. Computer-assisted quality control in tree-ring dating and measurement. Tree-Ring Bulletin, 43 : 51-67.

Jacoby G, D’Arrigo R, Davaajamts T. 1996. Mongolian tree rings and 20th-century warming. Science, 273(5276): 771-773.

Jacoby G, Pederson N, D'Arrigo R. 2003. Temperature and precipitation in Mongolia based on dendroclimatic investigations. Chinese Science Bulletin, 48(14): 1474-1479.

Kang E S, Cheng G D, Lan Y C, et al. 1999. A model for simulating the response of runoff from the mountainous watersheds of inland river basins in the arid area of Northwest China to climatic changes. Science in China Series D: Earth Sciences, 29(Suppl. 1): 52-63.

Kang S C, Zhang Y J, Qin D H, et al. 2007. Recent temperature increase recorded in an ice core in the source region of Yangtze River. Chinese Science Bulletin, 52(6): 825-831.

Kang X C, Graumlich L J, Sheppard P. 1997. A 1835 a tree-ring chronology and its preliminary analyses in Dulan region, Qinghai. Chinese Science Bulletin, 42(13): 1122-1124.

Kang X C, Zhang Q H, Graumlich L J, et al. 2000. Reconstruction and variation of climate in Dulan region, Qinghai during last 2000 a. Advance in Earth Sciences, 15(2): 215-221. (in Chinese)

Kang X C, Chen G D, Kang E S, et al. 2002. Based tree rings data reconstruction over 1000-year streamflow of mountain pass in Heihe River. Science in China Series D: Earth Sciences, 32(8): 675-685.

Kang X C, Cheng G D, Chen F H, et al. 2003. A record of drought and flood series by tree-ring data in the middle section of Qilian Mountain since 904 A.D. Journal of Glaciology and Geocryology, 25(5): 518-525. (in Chinese) 
Körner C. 1998. A re-assessment of high elevation treeline positions and their explanation. Oecologia, 115(4): 445-459.

Kundzewicz Z W. 1997. Water resources for sustainable development. Hydrological Sciences Journal, 42(4): 467-480.

LaMarche V C Jr. 1974. Paleoclimatic inferences from long tree-ring records intersite comparison shows climatic anomalies that may be linked to features of the general circulation. Science, 183(4129): 1043-1048.

Lazarus B E, Schaberg P G, DeHayes D H, et al. 2004. Severe red spruce winter injury in 2003 creates unusual ecological event in the northeastern United States. Canadian Journal of Forest Research, 34(8): 1784-1788.

Li L, Wang Z Y, Wang Q C. 2006. Inflence of climatic change on flow over the upper reaches of Heihe River. Scientia Geographica Sinica, 26(1): 40-46. (in Chinese)

Li Z J, Li X B, Xu Z M. 2010. Impacts of water conservancy and soil conservation measures on annual runoff in the Chaohe River Basin during 1961-2005. Journal of Geographical Sciences, 20(6): 947-960.

Li Z S, Zhang Q B, Ma K P. 2012. Tree-ring reconstruction of summer temperature for A.D. 1475-2003 in the central Hengduan Mountains, Northwestern Yunnan, China. Climatic Change, 110(1-2): 455-467.

Liang E Y, Shao X M, Eckstein D, et al. 2006. Topography- and species-dependent growth responses of Sabina przewalskii and Picea crassifolia to climate on the northeast Tibetan Plateau. Forest Ecology and Management, 236(2-3): 268-277.

Liang E Y, Shao X M, Qin N S. 2008. Tree-ring based summer temperature reconstruction for the source region of the Yangtze River on the Tibetan Plateau. Global and Planetary Change, 61(3-4): 313-320.

Liang E Y, Shao X M, Liu X H. 2009. Annual precipitation variation inferred from tree rings since A.D. 1770 for the western Qilian Mts., northern Tibetan Plateau. Tree-Ring Research, 65(2): 95-103.

Liu L S, Shao X M, Liang E Y, et al. 2006. Tree-ring records of Qilian Juniper's growth and regeneration patterns in the central Qilian Mountains. Geographical Research, 25(1): 53-61. (in Chinese)

Liu X H, Qin D H, Shao X M, et al. 2005. Temperature variations recovered from tree-rings in the middle Qilian Mountain over the last millennium. Science in China Series D: Earth Sciences, 48(4): 521-529.

Liu Y, Shi J F, Shishov V, et al. 2004. Reconstruction of May-July precipitation in the north Helan Mountain, Inner Mongolia since A.D. 1726 from tree-ring late-wood widths. Chinese Science Bulletin, 49(4): 405-409.

Liu Y, Linderholm H W, Song H M, et al. 2006. Temperature variations recorded in Pinus tabulaeformis tree rings from the southern and northern slopes of the central Qinling Mountains, central China. Boreas, 38(2): 285-291.

Liu Y, An Z S, Linderholm H W, et al. 2009. Annual temperatures during the last 2485 years in the mid-eastern Tibetan Plateau inferred from tree rings. Science in China Series D: Earth Sciences, 52(3): 348-359.

Luckman B H, Wilson R J S. 2005. Summer temperatures in the Canadian Rockies during the last millennium: a revised record. Climate Dynamics, 24(2-3): 131-144.

Ma J Z, Wang X S, Edmunds W M. 2005. The characteristics of ground-water resources and their changes under the impacts of human activity in the arid northwest China - a case study of the Shiyang River Basin. Journal of Arid Environments, 61(2): 277-295.

Mann M E, Lees J M. 1996. Robust estimation of background noise and signal detection in climatic time series. Climatic Change, 33(3): 409-445.

Mann M E, Bradley R S, Hughes M K. 1999. Northern Hemisphere temperatures during the past millennium: inferences, uncertainties, and limitations. Geophysical Research Letters, 26(6): 759-763.

Mann M E. 2002. Little ice age. In: MacCracken M C, Perry J S. Encyclopedia of Global Environmental Change. Oxford: Blackwell Science, 1: 504-509.

Mann M E, Zhang Z H, Rutherford S, et al. 2009. Global signatures and dynamical origins of the Little Ice Age and Medieval Climate Anomaly. Science, 326(5957): 1256-1260.

Mantua N J, Hare S R, Zhang Y, et al. 1997. A Pacific interdecadal climate oscillation with impacts on salmon production. Bulletin of the American Meteorological Society, 78(6): 1069-1079.

Mantua N J, Hare S R. 2002. The Pacific decadal oscillation. Journal of Oceanography, 58(1): 35-44.

Michaelsen J. 1987. Cross-validation in statistical climate forecast models. Journal of Climate and Applied Meteorology, 26(11): 1589-1600.

Misson L, Rathgeber C, Guiot J. 2004. Dendroecological analysis of climatic effects on Quercus petraea and Pinus halepensis radial growth using the process-based MAIDEN model. Canadian Journal of Forest Research, 34(4): 888-898.

Mitchell T D, Jones P D. 2005. An improved method of constructing a database of monthly climate observations and associated high-resolution grids. International Journal of Climatology, 25(6): 693-712.

Pederson N, Jacoby G C, D’Arrigo R D, et al. 2001. Hydrometeorological reconstructions for Northeastern Mongolia derived from tree rings: 1651-1995. Journal of Climate, 14(5): 872-881.

Pederson N, Cook E R, Jacoby G C, et al. 2004. The influence of winter temperatures on the annual radial growth of six 
northern range margin tree species. Dendrochronologia, 22(1): 7-29.

Percival D B, Walden A T. 1993. Spectral Analysis for Physical Applications. Cambridge: Cambridge University Press, 583.

Qin C, Yang B, Bräuning A, et al. 2011. Regional extreme climate events on the northeastern Tibetan Plateau since AD 1450 inferred from tree rings. Global and Planetary Change, 75(3-4): 143-154.

Saenko O A. 2006. Influence of global warming on baroclinic rossby radius in the ocean: a model intercomparison. Journal of Climate, 19(7): 1354-1360.

Sano M, Furuta F, Sweda T. 2009. Tree-ring-width chronology of Larix gmelinii as an indicator of changes in early summer temperature in east-central Kamchatka. Journal of Forest Research, 14(3): 147-154.

Shao X M, Fan J M. 1999. Past climate on west Sichuan Plateau as reconstructed from ring-widths of dragon spruce. Quaternary Sciences, (1): 81-89. (in Chinese)

Shao X M, Huang L, Liu H B, et al. 2005. Reconstruction of precipitation variation from tree rings in recent 1000 years in Delingha, Qinghai. Science in China Series D: Earth Sciences, 48(7): 939-949.

Sheppard P R, Tarasov P E, Graumlich L J, et al. 2004. Annual precipitation since 515BC reconstructed from living and fossil juniper growth of Northeastern Qinghai Province, China. Climate Dynamics, 23(7-8): 869-881.

Shi Y F, Zhang X S. 1995. Influence and future trends of climate variation on water resources in the arid area in the northern China. Science in China Series B: Chemistry, 25(9): 968-977.

Shi Y F, Shen Y P, Hu R J. 2002. Preliminary study on signal, impact and foreground of climatic shift from warm-dry to warm-humid in northwest China. Journal of Glaciology and Geocryology, 24(3): 219-226. (in Chinese)

Stewart I T, Cayan D R, Dettinger M D. 2004. Changes in snowmelt runoff timing in western North America under a 'business as usual' climate change scenario. Climatic Change, 62(1-3): 217-232.

Stokes M A, Smiley T L. 1968. An Introduction to Tree-ring Dating. Chicago: University of Chicago Press, 21-60.

Tan M, Liu T S, Hou J Z, et al. 2003. Cyclic rapid warming on centennial-scale revealed by a 2650-year stalagmite record of warm season temperature. Geophysical Research Letters, 30(12): 1617.

Tessier L, Guibal F, Schweingruber F H. 1997. Research strategies in dendroecology and dendroclimatology in mountain environments. Climatic Change, 36(3-4): 499-517.

Thompson L G, Mosley-Thompson E, Brecher H, et al. 2006. Abrupt tropical climate change: past and present. Proceedings of the National Academy of Sciences of the United States of America, 103(28): 10536-10543.

Tian Q H, Gou X H, Zhang Y, et al. 2007. Tree-ring based drought reconstruction (A.D. 1855-2001) for the Qilian Mountains, Northwestern China. Tree-Ring Research, 63(1): 27-36.

Wang H J. 2006. Linkage between the Northeast Mongolian precipitation and the northern hemisphere zonal circulation. Advances in Atmospheric Sciences, 23(5): 659-664.

Wang L L, Shao X M, Huang L, et al. 2005. Tree-ring characteristics of Larix gmelinii and Pinus sylvestris var. Mongolica and their response to climate in Mohe, China. Acta Phytoecologica Sinica, 29(3): 380-385. (in Chinese)

Wang N A, Zhao Q, Li J J, et al. 2003. The sand wedges of the last ice age in the Hexi Corridor, China: paleoclimatic interpretation. Geomorphology, 51(4): 313-320.

Wang S W, Zhu J H, Cai J N. 2004. Interdecadal variability of temperature and precipitation in China since 1880. Advances in Atmospheric Sciences, 21(3): 307-313.

Wang S W, Wen X Y, Lou Y, et al. 2007. Reconstruction of temperature series of China for the last 1000 years. Chinese Science Bulletin, 52(23): 3272-3280.

Wigley T M L, Briffa K R, Jones P D. 1984. On the average value of correlated time series, with applications in dendroclimatology and hydrometeorology. Journal of Applied Meteorology, 23(2): 201-213.

Wilson R J S, Luckman B H. 2003. Dendroclimatic reconstruction of maximum summer temperatures from upper treeline sites in Interior British Columbia, Canada. The Holocene, 13(6): 851-861.

Wu X D, Shao X M. 1995. Status and prospects of dendrochronological study in Tibetan Plateau. Dendrochronologia, 13: $89-98$.

Xu J H, Chen Y N, Lu F, et al. 2011. The nonlinear trend of runoff and its response to climate change in the Aksu River, western China. International Journal of Climatology, 31(5): 687-695.

Yadav R R, Park W K, Singh J, et al. 2004. Do the western Himalayas defy global warming? Geophysical Research Letters, 31(17): L17201.

Yang B, Braeuning A, Johnson K R, et al. 2002. General characteristics of temperature variation in China during the last two millennia. Geophysical Research Letters, 29(9): 38-1-38-4.

Yang B, Kang X C, Bräuning A, et al. 2010. A 622-year regional temperature history of southeast Tibet derived from tree rings. The Holocene, 20(2): 181-190. 
Yang B, Qin C, Bräuning A, et al. 2011. Rainfall history for the Hexi Corridor in the arid northwest China during the past 620 years derived from tree rings. International Journal of Climatology, 31(8): 1166-1176.

Yao T D, Qin D H, Xu B Q, et al. 2006. Temperature change over the past millennium recorded in ice cores from the Tibetan Plateau. Advances in Climate Change Research, 2(3): 99-103. (in Chinese)

Yuan L. 1994. Disaster and famine history in northwest China. Lanzhou: Gansu People's Publishing House, 243-320. (in Chinese)

Yuan Y J, Shao X M, Wei W S, et al. 2007. The potential to reconstruct Manasi River streamow in the northern Tien Shan Mountains (NW China). Tree-Ring Research, 63(2): 81-93.

Zhang Q B, Cheng G D, Yao T D, et al. 2003. A 2326-year tree-ring record of climate variability on the northeastern Qinghai-Tibetan Plateau. Geophysical Research Letters, 30(14): 1739.

Zhang Q B, Qiu H Y. 2007. A millennium-long tree-ring chronology of Sabina przewalskii on northeastern Qinghai-Tibetan Plateau. Dendrochronologia, 24(2-3): 91-95.

Zhang X L, He X Y, Li J B, et al. 2011. Temperature reconstruction (1750-2008) from Dahurian larch tree-rings in an area subject to permafrost in Inner Mongolia, Northeast China. Climate Research, 47(3): 151-159.

Zhang Y, Tian Q H, Gou X H, et al. 2011. Annual precipitation reconstruction since AD 775 based on tree rings from the Qilian Mountains, northwestern China. International Journal of Climatology, 31(3): 371-381.

Zhou S Q, Kang S C, Gao T G, et al. 2010. Response of Zhadang Glacier runoff in Nam Co Basin, Tibet, to changes in air temperature and precipitation form. Chinese Science Bulletin, 55(20): 2103-2110.

Zhu H F, Zheng Y H, Shao X M, et al. 2008. Millennial temperature reconstruction based on tree-ring widths of Qilian juniper from Wulan, Qinghai Province, China. Chinese Science Bulletin, 53(24): 3914-3920.

Zhu H F, Fang X Q, Shao X M, et al. 2009. Tree ring-based February-April temperature reconstruction for Changbai Mountain in Northeast China and its implication for East Asian winter monsoon. Climate of the Past, 5(4): 661-666.

Zhu H F, Shao X M, Yin Z Y, et al. 2011. Early summer temperature reconstruction in the eastern Tibetan Plateau since AD 1440 using tree-ring width of Sabina tibetica. Theoretical and Applied Climatology, 106(1-2): 45-53. 